\title{
Struggle towards Inclusion in Ethiopia: A Look at Teachers' and Principals' Attitudes
}

\author{
Anteneh Tadesse Asmamaw \\ Lecturer, Department of Educational Planning \& Management, Hawassa University
}

\begin{abstract}
Teachers and principals are seen as key persons to implement inclusive education. Positive attitudes are therefore argued as playing a considerable role in implementing educational changes successfully. The primary purpose of this study was to examine the attitudes of regular secondary school teachers'\& principals' attitudes toward inclusion of students with disabilities in Hawassa University Technology Village, Sidama Zone, SNNPR, Ethiopia. Particularly, the study explored the factors that may impact the attitudes of general education teachers toward including students with disabilities. The factors examined were experience, professional development, and principal support. The study adopted a mixed research methodology, with 100 secondary school teachers and 8 principals as participants from four randomly selected regular secondary schools. Questionnaires and interviews were used as instruments of data collection. The interview data were analyzed using thematic analysis and the quantitative results were tabulated with percentages. Spearman's correlation coefficient were also used to determine teachers' attitudes toward inclusion, involvement in professional development, and perceived support from administrators. The findings of this study revealed that teachers and principals agreed with inclusion philosophically but were somewhat dubious about the amount of services that could be provided. They felt that students with disabilities would benefit socially but would be at a disadvantage academically. The data analysis also indicated the strongest relationships between teachers' attitudes toward including students with disabilities and two factors; professional development and principal support. Moderate correlations were indicated between teacher attitudes and the courses completed by teachers that focused on inclusion as well as the number of years including students with disabilities. The weakest correlation identified by the data was between the teachers' attitudes toward including students with disabilities and the number of years of teaching experience. It is recommended by this study that awareness-raising about disability is a good step towards an equal position of students with disabilities in the schools in particular and people with disabilities in the society in general. Changes at policy level and support facilities for special needs students as an explicit concern are needed to achieve this equalization.
\end{abstract}

Keywords: Teachers\& principals attitudes, Inclusive education, Students with disability

\section{INTRODUCTION}

Historically, persons with disabilities have been treated as "invalid" or "inferior" and in need of very special protection and thus as not being able to benefit from education. This conceptualization led to exclusion and the construction of institutions to accommodate these children. The development of the field of special education has involved a series of stages during which education systems have explored different ways of responding to children with disabilities, and to students who experience difficulties in learning (Whittier \& Hewitt, 1993). In recent years, the appropriateness of segregated education system has been challenged, both from human rights perspective and from the point of view of effectiveness. A shift towards greater understanding led an eventual benefit that all children belonged in the same school system and could not be separated. As a result, inclusion started in the west parallel to special education which began in the late nineties and early twenties (UNESCO 2009). Inclusion simply means the educational placement of students with special educational needs (SEN) in the general education classroom for most of the school day with appropriate support and services (Booth and Ainscow 2002). Proponents of the regular education imitative strongly argue that by all measures inclusive education is the best conceptual and methodological approach aimed at achieving quality education by making changes in the mainstream education system to accommodate the needs of all learners regardless of their differences (Avramidis 2000). These advocates strongly argue that service provision outside the regular classroom has led to discontinuity in instruction, reduction of curricular options for students with special needs, and education with a limited scope. A 'one size fits all' types of teaching method will not be the best method of teaching any more (Ibid.).

As a result of the regular education initiative, over the past 30 years, international and national legislations and public attitudes have brought radical changes in the educational provisions of students with 
special needs (UNESCO 2009). Recently, there has been a much stronger commitment to educating all children with special needs in regular schools including those with severe learning difficulties (Cook, et. al, 1999). The instruction of students with disabilities is no longer associated with separate, "pull out" programs; instead, most students with disabilities are presently being taught in regular classrooms with their non-disabled peers (Raj 2002).

In Ethiopia, the major support for placement of individuals with disabilities into inclusive settings derives from the Education for All Disabled Children Act (2006), now known as the National Plan of Action of Persons with Disabilities Act (MoE 2012-2021).This Act set the stage for the regular classroom placement of students with disabilities and prompted significant changes in our system of public education (MoE 2012). As public schools move towards inclusion and the enrolment of students with disabilities in mainstream schools increases, a major concern that emerges is the potential impact of the attitudes of regular school teachers and principals toward these students (Asrat 2013; Tirusew 1999). A significant portion of the literature further indicated that, the attitudes and behaviors of educators toward any individual student can either enable the pupil to progress intellectually, socially, and emotionally, or can inhibit the child's opportunities for learning and growth (Oldfield 2009; Riemer 2004; Raj 2002 ; Cook 1999 ). The literature also suggests that in order to improve teachers' attitudes toward including students with disabilities, schools will need to focus on delivering effective professional development focused on inclusion and support provided by the administration.

\section{Rationale for the study}

In Ethiopia, the inclusion of disabled students is expected to increase significantly in the future as greater numbers of children with special learning needs attend public schools (Tirusew, 1999). As a result, principals and teachers will have more responsibility regarding the inclusion of special education students into the regular classroom. As educational services to students with disabilities change there is an essential need to describe and analyze the attitudes and behavior of teachers and principals that are relevant to the inclusion of students with disabilities in mainstream schools. However, little is known to date about what factors might influence the attitudes of regular secondary education teachers and principals toward including students with disabilities in Ethiopia, particularly in Hawassa University Technology Village. Thus, an examination is needed in order to determine the major factors that may influence the attitudes of teachers and principals toward the inclusion of students with disabilities. The study can be helpful to policy makers, school boards, principals, and teachers in providing a better understanding of the type of positive attitudes that encourage inclusive practices in regular secondary schools. Particularly, this study might help Hawassa University management and academic community to identify attitudinal barriers to inclusion and provide training to raise the awareness of secondary school teachers and principals.

\section{Objectives of the study}

The main objective of this study was to examine the factors that may influence the attitudes of regular secondary education teachers and principals toward including students with disabilities. Specifically, this study looked at how professional development, experience in including students with disabilities, and administrative support may impact the attitudes of teachers including students with disabilities.

\section{Research questions}

This study tried to find answers to the following basic questions:

1. What attitudes do regular secondary education teachers and principals have toward including students with disabilities?

2. What are the major factors that influence the attitudes of teachers and principals toward inclusion of students with disabilities?

3. What elements of professional development influence regular education secondary teachers' attitudes toward inclusion?

4. How do teacher experience \& principal support impact teachers' attitudes toward inclusion?

\section{METHODOLOGY}

The study used mixed research methodology. Both quantitative and qualitative methods are selected because in combination they provide the best opportunity to address the questions set. It makes the triangulation of the evidence possible as well as that the various methods complement each other in investigating the research issues. This decision is taken by the notion of 'fitness for purpose' that governs the research design (Creswell 2004: 73). He argues "you need not be the prison of a particular method when carrying out an enquiry". It is thought that every method has its weakness, but weakness varies for methods; so combining methods will reduce weakness and have the advantages of strengths (ibid.). 


\section{Participants}

Secondary (9th\& 10thgrade) general education teachers and principals from Hawassa University Technology Village Secondary Schools were surveyed. A total of 100 teachers and 8 principals participated in this study. Teachers were selected using cluster simple random technique while principals were included using purposive sampling because the non-probabilistic selection of subjects helps to obtain information rich cases for investigation. The study utilized surveys and interviews as a data collection tool to gauge the attitudes of general education teachers and the factors that may influence their attitudes. Teachers responded to both questionnaires and interviews while principals responded to interviews only. The interview questions focused on general attitudes toward including students with disabilities, perception of principal and special education support, and their experience in professional development workshops that focused on inclusion.

\section{Sampling, measures and procedures}

In order to collect data for quantitative analysis, a combination of two set of established surveys and demographic data were used. Cochran's (1998) 20 question STATIC survey determined teachers' attitudes toward inclusion and was combined with Littrell et al. (1994) 40-item survey to measure principal support. In addition, four demographic questions relating to experience and amount of pre-service and professional development involving inclusion. The final survey consisted of 64 items. The questionnaires were administered face to face to teachers at four secondary schools within Hawassa University Technology Village. Teachers were briefed on the purpose of the study as well as a statement of confidentiality. To obtain qualitative data, selected participants were contacted in order to conduct interviews at the participant's convenience for date, time and location inside the school setting. Interviews were recorded using a digital recorder and transcribed by the researcher.

\section{Method of data analysis}

An average score was calculated for each participant for the constructs of attitudes (items 5-24) as well as principal support (items 25-64). In order to determine a possible relationship between the variables attitudes and experience, a spearman correlation was performed using the average score of the attitudes construct and items 1 and 2 of the survey. The variables of attitudes and pre-service/professional development were examined by performing a spearman correlation between the average score of the attitudes construct and items 3 and 4 of the survey. A spearman correlation was also used to determine if a relationship exists between the average score of attitudes and the overall score for principal support.

A spearman correlation represents a bi-variant measure of association (strength) of the relationship between two variables. It varies from 0 (random relationship) to 1 (perfect linear relationship) or -1 (perfect negative linear relationship). Strength of correlation (r) is indicated by the following: very strong between 1 and .7 , strong between .7 and .5 , moderate between .5 and .3 , and questionable between .3 and 0 . Participating teachers were also asked to volunteer for a follow up interview in order to elaborate on the quantitative results. Three teachers with less than five years experience and three teachers with five or more years of experience were randomly selected. The participants were asked to elaborate on their experiences with principal support, pre-service training, and professional development experiences. Data were analyzed using thematic analysis approach.

\section{RESULTS AND DISCUSSION}

\section{Respondents' background information}

Data was collected from the four secondary schools within Hawassa University Technology Village. In School A: student enrollment included 2270 students of which $11.1 \%$ have students with SEN. Student to teacher ratio was 65:1 and the average teacher experience was 11.1 years. School B: serviced 3786 students and $12.1 \%$ of those students had SEN. Average teacher experience was 13.7 years and the student to teacher ratio was 64:1. Student enrollment for School C was 1573 with $13.6 \%$ of those student receiving special education services. The average teacher experience was 13.7 years and the teacher to student ration was 66:1. School D: enrollment was at 3117 students with $13.6 \%$ of those students with SEN. The average teacher experience was 13.2 years and the student to teacher ratio was $65: 1$.

From the 100 questionnaires administered to participants only 92 were returned. Participants provided information regarding experience teaching, experience with inclusion, and amount of pre-service and professional development involving inclusion. According to the data obtained from the respondents, 19 teachers had 0 years experience with including students with disabilities, ten had 1-2 years experience, nine had 3-4 years, 19 had 5-7 years, and 35 teachers had 8 or more years experience with inclusion. The number of preservice courses teachers completed that focused on including students with special needs indicated 45 teachers completed 1 course, 19 had 2 courses and 28 teachers completed 3 or more courses. All of the 92 participants indicated that they had completed at least one course focusing on including students with disabilities. The 
participants were also asked to identify how many professional development workshops they completed that focused on inclusion. 37 teachers indicated zero professional workshops, 32 teachers reported 1-2 workshops, 18 indicated 3-4 workshops, and 5 indicated five or more professional development workshops.

\section{Major findings}

This section presents the major findings of the study pertaining to each research question:

\section{Teachers' Attitudes toward Inclusion of Students with Disabilities}

The findings of this study indicate that mainstream education teachers generally feel ill prepared to handle the various special needs of students with disabilities in their classroom. Many teachers (90\%) believe that they have not been given adequate time to learn how to work with students with disabilities before implementation occurred. The current study also revealed that $85 \%$ of the general educators surveyed were willing to accept a student with disabilities in their classroom, given appropriate training. Without support and training, less than $15 \%$ of the respondents were willing to accept these students in their general education classes. This investigation further indicates that teachers hold negative attitude toward inclusion, because: They feel (a) incompetent due to lack of training and preparation; (b) resentment for extra responsibility; (c) overburdened by additional demands on already heavy workloads. Cognizant of this fact, in an interview with teachers, they were asked to talk about learning and teaching activities in the classrooms and outside classrooms. Responses of students were quoted verbatim. One English teacher had this to say;

Inclusive education in our school is not realistic" and its implementation is difficult; we had only a semester (one course) training in special education. There is less support from principals. Besides, there is no single person trained in inclusive education. Then, he questions, how general education can respond appropriately to the needs of students with disabilities when it has such obvious difficulty accommodating the divergent student population that already exists? Our schools are not designed to address the needs of children with disabilities.

Another female teacher echoed her frustration as follows;

We are not even aware of what inclusion means, let alone to put it into practice, our buildings are not accessible to students with mobility problem, no sign language teacher and facilities for the hearing impaired, no adequate brail for students with visual impairment. I strongly believe this inclusion thing can work only in the western world where everything is in place.

From the above voices, it seems that many teachers ( $85 \%$ ) believe that special education students will not get enough attention in the regular classroom, while others feel that the regular education student will suffer because pupils with special needs will require the majority of the classroom teacher's time. These findings are consistent with the results suggested by previous research (Asrat 2013; Oldfield 2009; Raj 2002).

\section{Principals' Attitudes toward Inclusion}

The results of this study revealed that most principals $(90 \%)$ agreed with inclusion philosophically but were somewhat dubious about the amount of services that could be provided. One principal expressed his attitude towards inclusion as follows:

I believe all students regardless of their ability or disability have the right to be here and to be thought to the best of our abilities. We strive for 'excellence' and we go to great lengths to define what we mean by excellence that is when every student in the school is achieving to the best of their ability and enjoying learning without feeling segregated.

Another principal spoke about his inclusive beliefs \& role in terms of the needs of all of the students at his school as follows:

My role is to ensure appropriate instruction for every student in my building. I don't care what label they have. I just don't care. I really think the question is simpler than we are making it.

However, still a significant majority $(75 \%)$ of the principals felt that the students with disabilities would benefit socially but would be at a disadvantage academically in mainstream schools. They reported that, although inclusion would help to promote understanding of individual differences among students, it would compromise the amount of time the teacher had to work with the majority of the students due to the amount of attention that would be required for students with disabilities. The principals were also concerned about the accessibility of their buildings, and that the significant amount of time that would be required of teachers to work with these students would reduce their overall effectiveness with the majority of students. Cognizant of this fact, one school principal gave the following typical response on the burden of including students with disabilities in large classrooms:

It is difficult for teachers to teach effectively in a class of over sixty students with more than one student with special needs, they spend almost half of school time work on attending to these students and this is the first time some of us have students who need a lot of help to cope with everything in the class. 
In a nutshell, based on the data obtained from the respondents, one can say that teachers and principals hold some positive attitude towards inclusion of students with disability in mainstream schools provided adequate training and professional support is delivered. The findings showed that most of the target schools were used to be quite academic in their focus in the past years, but is now shifting towards catering for diversity in abilities, culture and language. However, principals still marginally accept students who require extra time by a teacher to do non-academic duties. As a result, students with multiple or severe disabilities were unacceptable in the regular classrooms.

\section{Factors that Impact the Attitudes of Secondary School Teachers toward Including Students with Disabilities}

The data analysis demonstrated a strong correlation between teachers attitudes toward including students with disabilities and number of professional development workshops focusing on inclusion $(\mathrm{r}=.628)$. A strong correlation was also indicated between teacher attitudes and principal support $(\mathrm{r}=.546)$. Within the principal support constructs, strong correlations were also indicated between teachers attitudes and emotional support $(\mathrm{r}=.506)$, instrumental support $(\mathrm{r}=.528)$, and informational support $(\mathrm{r}=.529)$. Moderate correlations were indicated between attitudes and courses completed by teachers that focused on inclusion $(\mathrm{r}=.466)$ and number of years including students with disabilities $(r=.465)$. The weakest correlation identified in the data analysis was between the teachers' attitudes toward including students with disabilities and the number of years of teaching experience $(\mathrm{r}=.223)$.

Within the interview portion, challenges identified by teachers with less than five years of teaching experience, included lack of resources, technology, time constraints and lack of sufficient support both from administrators and special needs staff. Common themes identified with resources included strategies to keep students engaged, assistance in scaffolding or differentiating instruction and strategies dealing with behavioral issues. All three teachers expressed concerns with time constraints with a primary concern for time to adequately plan for their students with disabilities. When asked to identify challenges in implementing inclusion, two of the three teachers with five or more years of experience indicated that they do not have issues with including students in their classrooms. Both of these teachers indicated that it was difficult in the beginning of their career but have since learned effective strategies to provide quality instruction to students with disabilities. One teacher stated that she felt "very comfortable now including students with disabilities". The third teacher with five or more years of experience reflected similar themes as the teachers with less experience including time constraints and resources such as support of special education staff and parents.

In order to identify potential factors that may impact teachers' attitudes toward including students with disabilities, the interview participants were questioned about their perceptions of a successful inclusion program. One of the common themes when asked about elements of successful inclusion from all three of the teachers with less than five years of experience was the importance of parent support. One of the teachers stated, "I think that open and productive communication between the teacher and parent is important". Two of the teachers indicated the importance of being organized and prepared while the third offered the importance of seeking out professional development to support classroom instruction.

Two common themes surfaced when the teachers with five or more years of experience were asked what factors they attribute to successful inclusion. First, the importance of support and second, the importance of resources, was summed up by one teacher's statement, "Having a good staff and resources to help me". Having additional support staff was identified by all teachers as an important factor in successfully including students with disabilities. Resources including materials and technology were also identified by these teachers as important factors for inclusion. According to the six interview participants, the three most common factors in a successful inclusion program are availability of resources and support from parents and additional staff.

\section{Elements of Professional Development that affect Secondary Teachers' Attitudes toward Inclusion}

According to this study, the amount of professional development activities completed that focused on inclusion had a strong correlation with a positive increase in attitudes toward inclusion of students with disabilities. These activities, based on teachers' feedback, should include but not be limited to direct information regarding specific disabilities, instructional accommodations and modifications, differentiated instruction, learning modalities, developing collaboration skills and integrating technology. Administrators and teachers should collaborate to determine their areas of need when planning professional development activities (Avramidis 2000).

Two areas of training including pre-service courses and professional development workshops were examined. Table 1 outlines the relationship between pre-service courses dealing with inclusion and attitudes of the teachers toward inclusion. A mild correlation $r=.466$ suggests a moderate relationship between the two variables. The number of professional development workshops pertaining to inclusion and the attitudes of teachers including students with disabilities is shown in Table 2. A correlation of $r=.628$, considered to be a strong correlation, indicates that there is a strong relationship between pre-service courses and professional 
development workshops dealing with inclusion and may have a positive impact on teachers' attitudes toward including students with disabilities.

Table 1: Attitudes and Pre-Service Courses

\begin{tabular}{|l|l|l|l|l|}
\hline \multicolumn{2}{|l|}{} & $\begin{array}{l}\text { Number of } \\
\text { pre-service } \\
\text { courses }\end{array}$ & $\begin{array}{l}\text { Attitude } \\
\text { Average }\end{array}$ \\
\hline \multirow{3}{*}{ Spearman's rho } & $\begin{array}{l}\text { Number of pre-service } \\
\text { courses }\end{array}$ & $\begin{array}{l}\text { Correlation } \\
\text { Coefficient }\end{array}$ & 1.000 & $.466^{* *}$ \\
\cline { 3 - 5 } & Sig. (2-tailed) &. & .000 \\
\cline { 3 - 5 } & $\mathrm{N}$ & 92 & 92 \\
\cline { 3 - 5 } & $\begin{array}{l}\text { Correlation } \\
\text { Coefficient }\end{array}$ & $.466^{* *}$ & 1.000 \\
\cline { 2 - 5 } & $\begin{array}{l}\text { Attitude } \\
\text { Average }\end{array}$ & Sig. (2-tailed) & .000 & 92 \\
\cline { 2 - 5 } & $\mathrm{N}$ & 92 & 92 \\
\cline { 2 - 4 } & &
\end{tabular}

Table 2: Attitudes and Professional Development

\begin{tabular}{|c|c|c|c|c|}
\hline & & & $\begin{array}{l}\text { Number of } \\
\text { PD } \\
\text { workshops }\end{array}$ & $\begin{array}{l}\text { Attitude } \\
\text { Average }\end{array}$ \\
\hline \multirow[t]{6}{*}{ Spearman's rho } & \multirow{3}{*}{$\begin{array}{l}\text { Number of } \\
\text { PD } \\
\text { workshops }\end{array}$} & $\begin{array}{l}\text { Correlation } \\
\text { Coefficient }\end{array}$ & 1.000 & $.628 * *$ \\
\hline & & Sig. (2-tailed) & . & .000 \\
\hline & & $\mathrm{N}$ & 92 & 92 \\
\hline & $\begin{array}{l}\text { Attitude } \\
\text { Average }\end{array}$ & $\begin{array}{l}\text { Correlation } \\
\text { Coefficient }\end{array}$ & $.628 * *$ & 1.000 \\
\hline & & Sig. (2-tailed) & .000 & . \\
\hline & & $\mathrm{N}$ & 92 & 92 \\
\hline
\end{tabular}

Interview questions dealing with professional development focused on effective elements of the workshops that focused on including students with disabilities. All six teachers indicated the importance of learning new instructional strategies to enhance their inclusive practices. Three reoccurring themes emerged; differentiated instruction, multimodality learning, and integrating technology. Four out of the six teachers stated that learning differentiated instructional techniques to meet the students at their instructional level was an important aspect of productive professional development.

\section{Impact of Experience Working with Disabled Students on Secondary School Teachers' Attitudes toward Inclusion}

Based on the information in Table 3, the correlation between the year a educator received their teaching certification and the attitudes toward including students with disabilities was $r=.223$ which suggests a weak or questionable relationship between these two variables. The number of years a teacher has taught does not appear to have a positive effect on their attitudes toward including students with disabilities. However, Table 4 displays the correlation between the number of years' experience a teacher has including students with special needs and their attitudes towards inclusion. The analysis shows $\mathrm{r}=.465$ which indicates a moderate correlation. This indicates that experience including students with disabilities may have a positive effect on the attitudes of teachers toward inclusion.

Table 3: Attitudes and Teaching Experience

\begin{tabular}{|c|c|c|c|c|}
\hline & & & $\begin{array}{l}\text { What year did } \\
\text { you obtain } \\
\text { your } \\
\text { Certification? }\end{array}$ & $\begin{array}{l}\text { Attitude } \\
\text { Average }\end{array}$ \\
\hline \multirow[t]{6}{*}{ Spearman's rho } & \multirow[t]{3}{*}{$\begin{array}{l}\text { What year did you obtain } \\
\text { your certification? }\end{array}$} & $\begin{array}{l}\text { Correlation } \\
\text { Coefficient }\end{array}$ & 1.000 & $.223 *$ \\
\hline & & Sig. (2-tailed) & . & .033 \\
\hline & & $\mathrm{N}$ & 92 & 92 \\
\hline & $\begin{array}{l}\text { Attitude } \\
\text { Average }\end{array}$ & $\begin{array}{l}\text { Correlation } \\
\text { Coefficient }\end{array}$ & $.223^{*}$ & 1.000 \\
\hline & & Sig. (2-tailed) & .033 & . \\
\hline & & $\mathrm{N}$ & 92 & 92 \\
\hline
\end{tabular}




\begin{tabular}{|c|c|c|c|c|}
\hline & & & $\begin{array}{l}\text { Number of } \\
\text { years } \\
\text { including } \\
\text { students }\end{array}$ & $\begin{array}{l}\text { Attitude } \\
\text { Average }\end{array}$ \\
\hline \multirow[t]{6}{*}{ Spearman's rho } & \multirow[t]{3}{*}{$\begin{array}{l}\text { Number of years including } \\
\text { students }\end{array}$} & $\begin{array}{l}\text { Correlation } \\
\text { Coefficient }\end{array}$ & 1.000 & $.465 * *$ \\
\hline & & Sig. (2-tailed) & . & .000 \\
\hline & & $\mathrm{N}$ & 92 & 92 \\
\hline & $\begin{array}{l}\text { Attitude } \\
\text { Average }\end{array}$ & $\begin{array}{l}\text { Correlation } \\
\text { Coefficient }\end{array}$ & $.465 * *$ & 1.000 \\
\hline & & Sig. (2-tailed) & .000 & . \\
\hline & & $\mathrm{N}$ & 92 & 92 \\
\hline
\end{tabular}

\section{Impact of Principal Support on the Attitudes of Teachers toward Including Students with Disabilities}

Table 5 displays the data regarding the relationship between the general education teachers' perception of principal support and their attitudes toward including students with disabilities. A strong correlation of $\mathrm{r}=$ .546 was noted between these two variables. This indicates that teachers who feel supported by their principal have an increased positive attitude toward including students with disabilities. Within the principal support factor, the constructs of emotional, instrumental, informational, and appraisal were examined against the teachers' attitudes toward including students with disabilities. Strong correlations were noted between attitudes and the constructs of emotional support $r=.506$ (see Table 10), instrumental support $r=.528$ (see Table 11), and informational support $\mathrm{r}=5.29$ (see Table 12) $\mathrm{r}=.529$. Table 13 displays the data regarding the last principal construct of appraisal which showed a correlation of $\mathrm{r}=.482$ which is considered a moderate relationship. All four principal support factors showed a correlation with positive teacher attitudes toward including students with disabilities. However, the data indicates that principal support in the form of emotional, instrumental, and informational support may have the greatest impact on teacher attitudes toward inclusion.

Table 5: Attitudes and Principal Support

\begin{tabular}{|c|c|c|c|c|}
\hline & & & $\begin{array}{l}\text { Attitude } \\
\text { Average }\end{array}$ & $\begin{array}{l}\text { Principal } \\
\text { Support } \\
\text { Average }\end{array}$ \\
\hline \multirow[t]{6}{*}{ Spearman's rho } & \multirow[t]{3}{*}{$\begin{array}{l}\text { Attitude } \\
\text { Average }\end{array}$} & $\begin{array}{l}\text { Correlation } \\
\text { Coefficient } \\
\end{array}$ & 1.000 & $.546^{* *}$ \\
\hline & & Sig. (2-tailed) &. & .000 \\
\hline & & $\mathrm{N}$ & 92 & 92 \\
\hline & $\begin{array}{l}\text { Principal } \\
\text { Support } \\
\text { Average }\end{array}$ & $\begin{array}{l}\text { Correlation } \\
\text { Coefficient }\end{array}$ & $.546 * *$ & 1.000 \\
\hline & & Sig. (2-tailed) & .000 &. \\
\hline & & $\mathrm{N}$ & 92 & 92 \\
\hline
\end{tabular}

The area of teachers' perception of principal support during the interviews revealed mixed responses. While all six teachers reported that their principal either offered or encouraged professional development, principal supported collaboration was another matter. When asked if their principal facilitated common collaboration time with special education staff only one teacher with less than five years of experience indicated the principal facilitates these meetings while the remaining two indicated that this does not happen at their school and any collaboration time is coordinated by the teachers themselves.

\section{CONCLUSIONS}

Teachers and principals attitudes can have a profound impact on students' educational growth and inclusive practices. The findings clearly showed that educators' favorable and unfavorable attitudes toward students with disabilities had a significant impact on the academic performance of students. From the questionnaires the respondents indicated that some teachers frustrated and affected academic performance of students with disabilities. The findings further revealed that there was a strong relationship between teachers' attitudes toward including students with disabilities and two factors: professional development and principal support. Moderate correlations were indicated between teacher attitudes and the courses completed by teachers that focused on inclusion as well as the number of years including students with disabilities. The weakest correlation identified by the data was between the teachers' attitudes toward including students with disabilities and the number of years of teaching experience. These findings are consistent with the results suggested by previous research (Asrat 2013; Oldfield 2009; Cook et.al 1999; Tirusew 1999). In conclusion, in order to increase the success of inclusion programs, school systems need to take into account teachers' and principals' 
attitudes and how to affect those attitudes in a positive manor. Schools need to focus on delivering effective professional development focused on inclusion and support provided by the administration.

\section{RECOMMENDATIONS}

Based on the findings of the study, the following recommendations were made to ensure the successful inclusion of students with disabilities in mainstream secondary schools:

* The study recommends that an effective teacher must have high expectations on all students without discriminating students with disabilities or discriminating other students on gender, social class and culture. Teachers should strive to raise the bar for every student through effective classroom interaction in order for each learner to reach his or her best potential. Teachers should work on an attitude that all students can achieve to the teacher's level of expectations thereby giving the sense of confidence too.

* Principals should examine the importance of their support of teachers attempting to include students with disabilities and in what aspects the support should take place. Teachers want their principals to keep them informed of special and inclusive education policies \& laws, applications, and procedures. They also expect to receive support in the form of being supplied with appropriate materials and adequate planning time.

* Teachers require and desire professional development activities that directly deal with inclusion. These activities, based on teachers' feedback, should include but not be limited to direct information regarding specific disabilities, instructional accommodations and modifications, differentiated instruction, learning modalities, developing collaboration skills and integrating technology.

\section{REFERENCES}

[1]. Asrat, D. (2013). Factors Affecting the Implementation of Inclusive Education in Primary Schools of Bahir-Dar Town Administration. Education Research Journal 3(3); pp.59- 67 Available online at http://www.resjournals.com/ERJ. Accessed on $16 / 04 / 17$.

[2]. Avramidis, E. (2000). A survey into mainstream teachers' attitudes towards the inclusion of children with special educational needs. Educational Psychology: An International Journal of Experimental Educational Psychology, 20(2), 191.

[3]. Booth, T. \& Aniscow M. (2002). Index for Inclusion: Developing learning and Participation in Schools. Bristol: Center for students on Inclusive Education.

[4]. Cochran, H. K. (1998). Differences in teachers' attitudes toward inclusive education as measured by the scale of teachers' attitudes toward inclusive classrooms (STATIC). Paper presented at the meeting of the Mid-Western Educational Research Association, Chicago.

[5]. Cook, B. G., Semmel, M. I., \& Gerber, M. M. (1999). Attitudes of principals and special education teachers toward the inclusion of students with mild disabilities: Critical differences of opinion. Remedial and Special Education, 20(4), 199.

[6]. Creswell,J. W. (2003). Research design: Qualitative, quantitative and mixed methods approach 2nd edition. Printed in California,

USA. SAGE Publications, Inc.

[7]. MoE (2012-2021). National Plan of Action of Persons with Disabilities. Ministry of Education. April 2012, Addis Ababa, Ethiopia.

[8]. Oldfield, J. R. (2009). Attitudes towards an inclusion classroom: A qualitative meta- synthesis study from 1997-2007. Pro-Quest LLC.

[9]. Raj, M. J. (2002). The factors that influence teachers' and principal's perceptions of inclusion. (Ed.D., Seton Hall University, $\quad$ College of Education and Human Services, NJ).

[10]. Riemer, T. E. (2004). Attitudes regarding the implementation of inclusion in the form of mainstreaming at a Chicago public school.

[11]. Tirusew, T. (1999). Inclusion of Children with Disability in Regular Schools: Challenges and Opportunities, the Ethiopian Journal of Education, 11(1): 6-9. Accessed on 5/05/17

[12]. UNESCO (2009). Education for All by 2015. Will We Make It? EFA Global Monitoring Report. UNESCO, Paris. Accessed on 15/05/17.

[13]. Whittier, K. S., \& Hewitt, J. S. (1993). Intervention in School and Clinic, 29(2), 84-88. 